\title{
UTILIZATION AND BENEFITS OF BIOGAS IN THE SETTLEMENTS ALONG THE SIDDHARTHA HIGHWAY IN SYANGJA DISTRICT, NEPAL
}

\section{Dilli Raj Gautam, PhD}

\author{
Associate Professor \\ Department of Geography Education \\ Tribhuvan University \\ drgautam16@gmail.com
}

\begin{abstract}
This paper aims at analyzing the benefits of biogas system installed along the Siddhartha Highway in Syangja district. Because of the low level of development, the rural households of Nepal are still utilizing the traditional energy resources. About 87 percent of the total energy requirements in Nepal are met by traditional sources of energy. Among them, 77.3 percent energy has been fulfilled by fuel wood alone. To reduce the household consumption of fuel wood energy and save the environment, time and money, biogas system was introduced in Nepal since 1955. However, 261650 biogas systems are installed in Nepal till now. Among them, 6716 plants are installed in Syangja district, of which 38.56 percent plants are located along the Siddhartha highway. According to the respondents, owing to their social prestige, pollution free indoor environment, easy for cooking, conservation of natural resources and reduced work for women and school children, they are satisfied with their biogas system.
\end{abstract}

Keywords: Installation, biogas, technology, energy, fuel wood, alternative, system, livelihood

\section{Introduction}

Biogas properly known as Gobargas in Nepal is a viable renewable energy technology for Nepal. Besides energy, it produces slurry which is very valuable manure for crop farming. Biogas plant has become popular in rural areas of Nepal to meet the increasing energy demand for growing population and their household requirement. Although, the installation of biogas plant in Nepal was started from 1955 its progress was moving at a glacial pace. Up to 1975 A.D. a few plants were built in different parts of the country. In the fiscal year 1975/ 76, 290 biogas plants were constructed with interest free loan from ADB/N (Silwal, 1999). However, there was a slow progress in plant installation. Therefore, the government of Nepal felt to promote the Gobergas Company (GGC) established in 1977 jointly by $\mathrm{ADB} / \mathrm{N}$ and Fuel Corporation. After that then GGC was given responsibility of advancing the development and promoting the installation of biogas plant extensively in Nepal. Initially, the drum type plants and later dome type of plants were installed. Before 1985, the rate of installation of biogas ranged between 100-300 plants per year. GGC had a target of 800 plants per year with a total of 4000 units to be completed within the period of 1985-1990. However, during the period, 3862 plants were constructed by the GGC (BSP, 2004).

Regarding the developmental phase of biogas system in Nepal, biogas support program (BSP) was initiated in 1992 as a joint venture of Asian Development Bank (ADB/N), Gobargas Company (GGC) and Netherlands Development Agency (SNV) Nepal. Later it was established in 2003 with the name of Biogas sector partnership Nepal (BSPNepal). Presently, the organization has successfully completed the Gobargas plants according to the demand of the households. By mid July 2011 Nepal has some 261650 household size biogas plants constructed in all 75 districts of Nepal (Rai, 2011). Out of these 241920 were installed by the BSP alone.

Biogas is the most important alternative and useful energy source which is technically feasible and economically viable than the other. Experience has shown that the rural people cannot use wind and solar energy because of high cost of installation. Thus, biogas installation is one of the appropriate substitutions for other energy sources. According to the estimation of 2005, the energy consumption in Nepal is 367 GJ in which the share of traditional energy is 87.71 percent, commercial 11.76 and renewable 0.53 percent. Out of the renewable energy, biogas has occupied 0.52 percent whereas micro hydro has sharing of 0.01 percent. The share of the solar and wind energy is negligible (WECS, 2006). As mentioned above, about 87 percent of the total energy in Nepal is met by fuel wood, crop residue and animal dung (Joshi et al., 2004) whereas fuel wood alone accounts for more than 77.3 percent (MOF, 2004). In Nepal, the dependency on forest for energy is very high and forests are being extremely exploited causing deforestation and environmental degradation. Currently, Nepal is facing the problem of energy. The demand of cooking and lighting is very high because of the increasing number of population and households. There are various alternative ways of obtaining the required energy resources for domestic consumption. Among them, biogas is one of the more efficient ways of 
supplying energy resources to Nepal. Regarding the potentiality of biogas in Nepal, the total households with cattle and buffalo was estimated to be 1.18 million in 2001 and an estimated biogas potentiality is 1.02 million plants of which 57 percent in plain, 37 percent in hills and 6 percent in remote hills or mountains can be installed at various phase (BSP, 2010/2011).

Presently, fire wood, liquefied gas, kerosene and electricity is used for energy. However, fire wood is becoming scarce and costly. Petroleum products, the most important form of commercial energy are totally imported in Nepal and financial burden is quite heavy. The exploitation of hydropower and solar energy is also difficult because of the high cost. Therefore, biogas remains the best alternative energy source which is technically and economically feasible.

\section{Materials and Methods}

The study is based on primary information obtained from the field survey. The primary data were collected during the field survey by structured questionnaire, interview and field observation. The responses of biogas plant owners are regarded as the major sources of field information. A purposive random sampling method was chosen for household survey to get data. Out of the total 2590 households, 256 households from 9 VDCs and 2 municipalities have been chosen for analysis. For secondary sources of information, various books, journals, periodicals and unpublished documents were consulted from where necessary literature database were extracted. The analysis of data is based on qualitative and quantitative approaches. Some percentage figures were also calculated. The data gathered from field survey and various data base are tabulated and analyzed.

\section{Installation of Biogas Plant in Syangja District}

Syangja is one of the 39 hill districts in Nepal and covers an area of 1164 sq. $\mathrm{km}$. The district is situated at the altitude of 366 meter (Keladi) to 2512 meter (Panchase Lekh) above the mean sea level characterized by subtropical, warm temperate and cold temperate climate. It has 60 Village Development Committees (VDCs) and 2 Municipalities with a population of 317,320 distributed in 64,746 households with an average household size of population 4.9 and the growth rate 4.9 percent. Out of the total households of the district, 9.9 percent are found to have installed the biogas of various sizes. However, 38 percent of the total installed plants of the district are located along the Siddhartha Highway (Fig.1).

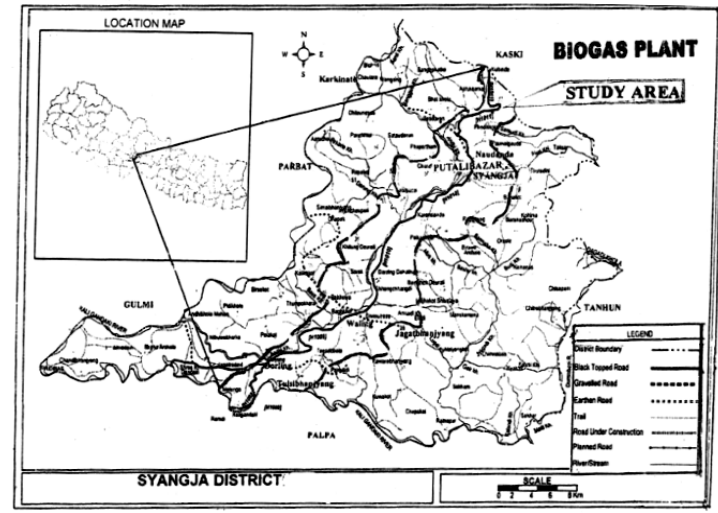

The sampled households account for 256 units with biogas system in the settlements along the Siddhartha Highway in Syangja district (Table 1).

\section{Table 1: Distribution of household with biogas plants by VDC/NP}

\begin{tabular}{|l|c|c|c|c|c|c|c|}
\hline Name of VDC/NP & \multirow{2}{*}{$\begin{array}{c}\text { HH with } \\
\text { biogas }\end{array}$} & \multirow{2}{*}{$\begin{array}{c}\text { Sample } \\
\text { plants }\end{array}$} & size & & \multicolumn{3}{|c|}{ Number of plants at sample household by volume } \\
\cline { 5 - 8 } & & & $6 \mathrm{~m} 3$ & $8 \mathrm{~m} 3$ & $10 \mathrm{~m} 3$ & $15 \mathrm{~m} 3$ \\
& & & & & & \\
\hline Chhangchhandi & 146 & 15 & $2(0.78)$ & $9(3.51)$ & $2(0.78)$ & $2(0.78)$ & - \\
\hline Darsing Dahathum & 144 & 14 & $1(0.39)$ & $8(3.12)$ & $3(1.17)$ & $1(0.39)$ & $1(0.39)$ \\
\hline Jagatradevi & 143 & 14 & $3(1.17)$ & $7(2.73)$ & $1(0.39)$ & $3(1.17)$ & - \\
\hline Khilung Deurali & 217 & 22 & $3(1.17)$ & $12(4.68)$ & $6(2.34)$ & $1(0.39)$ & - \\
\hline Malunga & 62 & 6 & $1(0.39)$ & $3(1.17)$ & $2(0.78)$ & - & - \\
\hline Phedikola & 33 & 3 & $1(0.39)$ & $2(0.78)$ & - & - & - \\
\hline Putalibazaar NP & 899 & 90 & $7(2.73)$ & $46(17.94)$ & $27(10.53)$ & $9(3.51)$ & $1(0.39)$ \\
\hline Sworek & 99 & 10 & $1(0.39)$ & $4(1.56)$ & $3(1.17)$ & $2(0.78)$ & - \\
\hline Tindobato & 85 & 6 & - & $5(1.95)$ & $1(0.39)$ & - & - \\
\hline Tulsibhanjyan & 192 & 19 & $1(0.39)$ & $13(5.07)$ & $3(1.17)$ & $2(0.78)$ & - \\
\hline Waling NP & 570 & 57 & $3(1.17)$ & $33(12.87)$ & $13(5.07)$ & $7(2.73)$ & $1(0.39)$ \\
\hline Total & 2590 & 256 & $23(8.98)$ & $142(55.46)$ & $61(23.82)$ & $27(10.54)$ & $3(1.17)$ \\
\hline
\end{tabular}

Source: Field survey, 2011.

Note: Figure in the parenthesis indicate the percentage of the total 
The size of the plant found in the study area are $4 \mathrm{~m}^{3}, 6 \mathrm{~m}^{3}, 8 \mathrm{~m}^{3}, 10 \mathrm{~m}^{3}$ and $15 \mathrm{~m}^{3}$ accounting for 8.98 percent, 55.46 percent, 23.82 percent, 10.54 percent and 1.17 percent respectively. The study reveals that out of the total sampled households, 72 percent have been found to be installed with attached toilet and 28 percent have been installed without attachment of the toilet.

Out of the total plants, 98.5 percent of the total plants are installed with the purpose of cooking energy and 1.5 percent of plants are installed even for lighting purpose as well along with cooking purpose. Likewise installation for combustion purpose is found to be nil (Table 2) because it needs a higher capacity plant and the larger quantity of dung. A large capacity biogas system may be found in the Tarai region only.

\section{Table 2: Distribution of biogas plants by category}

\begin{tabular}{|l|c|c|}
\hline Digester category & Number & Percent \\
\hline $\begin{array}{l}\text { Plants with dung and } \\
\text { excreta digester }\end{array}$ & 184 & 72 \\
\hline Plants with dung digester & 72 & 28 \\
\hline Total & 256 & 100 \\
\hline Stove and engine category & Number & Percent \\
\hline $\begin{array}{l}\text { Plants with cooking } \\
\text { stoves only }\end{array}$ & 251 & 98.5 \\
\hline $\begin{array}{l}\text { Plants with cooking } \\
\text { stoves and lamp }\end{array}$ & 5 & 1.5 \\
\hline $\begin{array}{l}\text { Plants with combustion } \\
\text { engines }\end{array}$ & Nil & Nil \\
\hline Total & 256 & 100 \\
\hline
\end{tabular}

Source: Field survey, 2011.

\section{Benefits of Biogas System}

According to the respondent, the chief purpose behind the installation of biogas system is cooking and boiling by setting the cooking stove in the kitchen. Its burning process is similar to liquefied petroleum gas (LPG). Due to the smokeless flame, the utensils remain neat and clean and cooking environment become healthier. It can also be used as a fuel in internal combustion engines. Such engines can be used in small scale industries where there is no electricity supply. The slurry produced by the system after the digestion of fresh dung can be used in substitution of chemical fertilizer.

\section{a) Social Benefits}

Installation of biogas reflects the social prestige. A quicker servicing of food and tea to the incoming guests was felt to be a social prestige. Because of the decreased firewood collection and cooking time some plant owners were engaged in informal education training programs and various social organizations.
Benefit for poverty alleviation: Majority of the plant owners have sold the collected fire wood to the hotels located along the side of the Siddhartha highway. Among them, 21 percent responded that they have been saving the money collected by selling fire wood. Thus, the daily saving of the small amount of money will also be helpful for poverty alleviation. Likewise, slurry is very valuable organic manure for crop farming. It is rich in nutrient content as compared to dung. As per norms established by the Gober gas company, the slurry produced from the biogas plant contains 1.6 percent nitrogen, 1.2 percent phosphorus and 1.0 percent potash in livestock dung. So, biogas is considered to be high quality organic manure. If the farmers use this manure, certainly they will get high yield in their field. It also supports to alleviate the poverty.

Benefit on women's health: Indoor air pollution and smoke exposure from the use of fuel wood, dung cakes and agricultural residue for cooking and heating in rural Nepal is amongst the worst in the world (Bajgain \& Shaya, 2004). Women and children are responsible for preparing food and working in the kitchen. Most of the biogas households expressed that, because of the reduction of smoke in kitchen they are no more suffering from respiratory problems. In this connection, the women working in the kitchen are free from cough and asthma disease. Furthermore, the women unanimously responded that at the time of fire wood collection they have experienced the bite of worms, snakes and injury from accidents that occur while walking with the load of fuel wood on the trail.

Benefit on children's education: Before installation of biogas plant, most of the children in the study area were sent to fire wood collection at the time of their study period. They spent 2-3 hours per day for fire wood collection. But nowadays, they have got free time to study. The time saved from the use of biogas has enabled female children to attend school which previously was not possible as they were involved with household chores and collection of fire wood. The children having lamps of biogas plant responded that they have felt convenience for reading or study even in the evening.

Benefit in reducing work load and saving time: The study reveals that after installation of biogas plant it reduced the work load of the family members, especially of the female members. It has saved the time of fire wood collection, cooking and washing utensils. Users' perception shows that household women without biogas plant spent 3 hours per day for firewood collection, 3 hours per day for cooking and about one hours per day for washing utensils, whereas women with the biogas plant have spent only 1 hour per day for firewood collection, 1.5 
hours per day for cooking and 0.5 hours per day for washing utensils (Table 3).

Table 3: Reduction of working time per day by work category

\begin{tabular}{|l|c|c|c|}
\hline $\begin{array}{c}\text { Category } \\
\text { of work }\end{array}$ & $\begin{array}{c}\text { Before } \\
\text { biogas } \\
\text { installation }\end{array}$ & $\begin{array}{c}\text { After } \\
\text { biogas } \\
\text { Installation }\end{array}$ & $\begin{array}{c}\text { Saving } \\
\text { time }\end{array}$ \\
\hline $\begin{array}{l}\text { Firewood } \\
\text { collection }\end{array}$ & 3 & 1 & 2 \\
\hline $\begin{array}{l}\text { Cooking } \\
\text { activity }\end{array}$ & 3 & 1.5 & 1.5 \\
\hline $\begin{array}{l}\text { Washing } \\
\text { Utensils }\end{array}$ & 1 & 0.5 & 0.5 \\
\hline Total & 7 & 3 & 4 \\
\hline
\end{tabular}

Source: Field Survey, 2011.

The women of the respondent family spent 7 hours a day in fire wood collection, cooking and washing utensils before biogas installation whereas they have saved 4 hours per day after installation of biogas plant. Consequently, they can allocate the saved time to other activities such as other household works, social works, agricultural activities, and other income generating activities.

\section{b) Economic Benefit}

Saving of fire wood, LPG and increment in agricultural production by using the slurry of the biogas plant indicate the economic benefit to the users. The biogas directly results in reducing the household consumption of fuel wood. It provides a financial gain to household by helping them get free from forest practice and engaging themselves in other income generating activities. Similarly, it reduces the consumption quantity of LPG, Kerosene and electricity.

Benefit from the cost of cooking fuel (firewood, LPG and kerosene): Burning of fire wood in our traditional fireplace is still the most popular method of cooking, especially in the rural areas of Nepal. However, in the households with the biogas plants in Syangja, biogas stoves have substituted traditional fireplace that used fire wood.

Table 4 reveals that out of the 256 households 68.75 percent households used to consume 105.6 tons fire wood before installation of biogas plant. Now they have consumed only 33.4 tons fire wood and have saved 72.1 tons of fuel wood cost Rs. 2.1 million. Similarly, 19.14 percent households had used 98 cylinder LP gas and now are saving 0.1 million rupees by reducing the consumption pattern due to the installation of biogas. Likewise, 4.29 kerosene fuel users have also saved Rs. 0.01 and 0.003 million rupees per months. Thus the households of the study area have been benefited from the reduced use of traditional and commercial cooking fuels by installing the biogas plant.

Benefit from reduced use of chemical fertilizer: The farmers of Nepal have used more chemical fertilizers on their agricultural fields. However, the farmers are experiencing that the use of fertilizer is reducing the productivity of the agricultural land. Therefore nowadays farmers are motivated towards the use of ordinary compost manure. The farmer of households with biogas plant responded that the slurry compost manure is more beneficial than ordinary compost manure. Evidently, the nitrogen, phosphorus and potash (NPK) can be found at higher quantity in slurry compost than in ordinary one. The slurry increases the physical feature, humus quality and fertility of soil. So, it is beneficial to use slurry compost manure in place of chemical fertilizers which helps in saving of money for the biogas owners and rising productivity of their agricultural farm.

Table 4: Monthly fuel use of household before and after installation of biogas

\begin{tabular}{|l|c|c|c|c|c|}
\hline \multirow{2}{*}{ Fuel type } & \multicolumn{2}{|c|}{$\begin{array}{c}\text { Average } \\
\text { quantity }\end{array}$} & Difference & $\begin{array}{c}\text { Cost } \\
\text { (Million NRs) }\end{array}$ & $\begin{array}{c}\text { Household } \\
\text { percent }\end{array}$ \\
\cline { 2 - 3 } & Before & After & & & 68.75 \\
\hline Firewood (Ton) & 105.6 & 33.4 & 72.1 & 2.1 & 19.14 \\
\hline LPG (Cylinder) & 98 & 24.5 & 73.5 & 0.1 & 4.19 \\
\hline Kerosene (Liter) & 275 & 82.5 & 192.5 & 0.01 & 7.81 \\
\hline Electricity (Unit) & 800 & 300 & 500 & 0.003 & 100.0 \\
\hline Total & & & & 2.213 & \\
\hline
\end{tabular}

Source: Field Survey, 2011 and personal computation. 
Table 5: Reduction of fertilizer per household per year by type of crops

\begin{tabular}{|l|c|c|c|c|}
\hline \multirow{2}{*}{ Types of crops } & \multicolumn{4}{l|}{ Reduced quantity of chemical fertilizers } \\
\cline { 2 - 5 } & Nitrogen & Phosphorus & Potash & Total \\
\hline Paddy & 3 & 2 & 4 & 9 \\
\hline Wheat & 6 & 3 & 5 & 14 \\
\hline Maize & 2 & 1 & 3 & 6 \\
\hline Vegetables & 3 & 2 & 1 & 9 \\
\hline Orange tree & 2 & 1 & 1 & 2 \\
\hline Others & 1 & - & 18 & 34 \\
\hline Total & 17 & 9 & & \\
\hline
\end{tabular}

Source: Field survey, 2011.

The farmers of respondent family have reduced the use of chemical fertilizer after the installation of biogas plant. They have kept minimum 3 cattle (cow / buffalo) in their home to supply the semi- liquefied dung into the digester. The farmers have used the compost slurry instead of using chemical fertilizer. Consequently, a household with biogas plant has reduced the quantity of nitrogen $17 \mathrm{~kg}$, phosphorus $9 \mathrm{~kg}$, potash $18 \mathrm{~kg}$ per year. Hence, each family has saved an amount of Rs. 2500 per year by reducing the chemical fertilizers in agricultural field. So, the respondents of the study area are economically benefited.

\section{c) Environmental Benefit}

Assessing the immediate environmental benefit is very difficult in household level. This should be seen in a wide context. The impact of biogas use on environment can be viewed from a number of perspectives. Among them, reduction in the deforestation ratio by reducing the quantity of fire wood collection to keep the cook free from indoor air pollution and to take the benefit from carbon trade is more significant.

\section{Benefit from conservation of forest and carbon trade:} Excess use of fire wood results deforestation. The biogas system has helped to reduce deforestation. This in turn has important implications for watershed management and soil erosion. Clearing of forest for agriculture has been a serious problem in study area. Production of slurry and use in agricultural field has helped to reduce the pressure o expanding the area of land cleared for agriculture. The following Table 4 shows the benefit of biogas on forest.

The 23 biogas systems with $4 \mathrm{~m}^{3}$ capacity have saved 744 tons fuel wood per year. Similarly, 142 biogas systems of $6 \mathrm{~m}^{3}$ capacity have saved 592 tons of fuel wood per year. Likewise, $8 \mathrm{~m}^{3}, 10 \mathrm{~m}^{3}$ and 15 $\mathrm{m}^{3}$ systems have saved 1920, 888 and 72 tons fuel wood per year. This quantity of saving fuel wood has supported to save $997.4 \mathrm{CO}_{2}$ equivalent carbon gas. However, according to the Biogas support programme 2010/2011, the quantity of GHG reduction per year per $\mathrm{HH}$ is 7.4 tons.

\section{Table 6: Size of biogas plant, fuel wood saving and carbon sequestration}

\begin{tabular}{|l|c|c|c|c|}
\hline Size of plant & Number of plants & $\begin{array}{c}\text { Average fuel } \\
\text { wood saving } \\
\text { (Tons per year) }\end{array}$ & $\begin{array}{c}\text { Net GHG saving/ } \\
\text { system per year }\end{array}$ & $\begin{array}{c}\text { Total } \\
\text { reduction of } \mathrm{CO}_{2} \text { per } \\
\text { year }\end{array}$ \\
\hline $4 \mathrm{~m}^{3}$ & 23 & 144 & 2.68 & 61.68 \\
\hline $6 \mathrm{~m}^{3}$ & 142 & 5920 & 3.92 & 556.64 \\
\hline $8 \mathrm{~m}^{3}$ & 61 & 1920 & 4.59 & 279.99 \\
\hline $10 \mathrm{~m}^{3}$ & 27 & 888 & 3.67 & 99.09 \\
\hline $15 \mathrm{~m}^{3}$ & 3 & 72 & NA & - \\
\hline Total & 256 & 9544 & - & 997.4 \\
\hline
\end{tabular}


Thus, the reduction in the use of fuel wood has contributed in reducing the prevailing high rate of deforestation in the country in general and reducing the $\mathrm{CO}_{2}$ level in the study areas in particular. According to estimation, one biogas plant has protected 1.25 trees per year. In this connection, the installations of 256 biogas plants have protected 320 trees per year in the study area. Hence, the reduction of fuel wood gathering activity by installing the biogas system has played a significant role on carbon sequestration.

Free from indoor air pollution: Smokeless nature of the biogas fuel helps to keep kitchen free from indoor air pollution. The use of biogas has helped significantly improve the indoor air quality of houses employing biogas stoves in place of wood stoves.

Table 7: Health Problems of the household cook in percentage

\begin{tabular}{|l|c|c|}
\hline $\begin{array}{l}\text { Disease } \\
\text { Category }\end{array}$ & $\begin{array}{l}\text { Before } \\
\text { biogas } \\
\text { installation }\end{array}$ & $\begin{array}{l}\text { After } \\
\text { biogas } \\
\text { installation }\end{array}$ \\
\hline T.B. & 0.1 & Nil \\
\hline Whooping cough & 1.8 & 0.7 \\
\hline Head ache & 1.8 & 0.3 \\
\hline Eye Burning & 2.0 & 0.1 \\
\hline Asthma & 0.2 & 0.1 \\
\hline $\begin{array}{l}\text { Combination of } \\
\text { two and more }\end{array}$ & 2.5 & 1.1 \\
\hline Total & 8.8 & 2.3 \\
\hline
\end{tabular}

Source: Field survey 2011 and personal computation.

The study reveals that among the respondents family 0.5 percent household cook has been found to be suffered from Tuberculosis Bacilli (T.B.) disease before the installation of biogas plant whereas the highest number i.e. 2.5 percent have suffered from various diseases related to indoor air pollution. It is clear from the table 5 that of the total household cook 8.8 percent had suffered from two or more respiratory diseases. However, after the installation of biogas system in their household only 2.3 percent cook of the family member suffered from indoor air pollution related diseases. Hence, 2/3 disease affected persons are now free from previous diseases. This may be the positive impact of biogas stoves.

\section{Conclusion}

It is obvious from the above discussion that the use of biogas has brought the significant improvement in the quality of life of the family members and reduction on the work of women, taking the responsibility of cooking in their kitchen. Presently, Biogas technology, one of the clean energy is being popular in Nepal especially in the rural areas where each and every household keeps cattle and buffalos. The observation shows that before installation of biogas plant. Majority of the household had used fire wood and agricultural residue for cooking. The large portion of using these fuels has declined after the installation of biogas system. The users have got a remarkable decrease in smoke and there by reduction of indoor air pollution. As a result, 2/3 cook of the respondent family have got rid of the diseases causing indoor air pollution. Respondents have also used the digested slurry in their fields for the substitution of chemical fertilizer. Liquid and dries slurry users have prepared compost manure with other waste product like straw, fodders, litters and other agricultural residue which has helped the fast drying of slurry. These types of slurry have optimum NPK content. By the use of this slurry, the farmers are benefitted with higher yield in their agricultural land. Most of the biogas owners are applying dried and liquid slurry especially for vegetables, food crops, orange tree, and other cash crops. Minimization of chemical fertilizer has shown the increase in the productivity of the land. Hence, the installation of biogas system in Syangja has protect the indoor environment, checking the rate of deforestation, saving the fire wood, reducing work load mainly of women and children, saving the time and providing the appropriate toilet facility. The facility of biogas lamp is the next significant contribution of the biogas plant.

\section{References}

Bajgain, S., \& Shakya, I. (2004). A successful model of public private partnership for rural households energy supply. Kathmandu: Nepal Biogas Support Programme, Kathmandu.

Biogas Sector Partnership (BSP). (2011). Potential of biogas in Nepal, BSP Year Book, 2011, Kathmandu.

Biogas Support Program (BSP). (2004). BSP Year Book 2004, Kathmandu.

JoshiC.B., \&Shrestha, B.P. (2004). Microhydropower: A viable renewable energy technology for Nepal, Journal of Engineering, 4, 80-86.

Ministry of Finance (MoF). (2004). Economic survey 2003/2004. Kathmandu: HMG, Nepal

Rai, S. (2011). BSP Year Book, 2010/2011. Kathmandu: Biogas Support Program.

Silwal, B. B. (1999). Review of the biogas program in Nepal. (Research Report, 42). Kathmandu: Winrock International.

Water and Energy Commission Secretariat (WECS). (2006). Energy synopsis report 2006. Kathmandu: WESC.

Winrock and Eco Securities. (2004). Nepal Biogas Program. Kathmandu: Winrock and Eco securities. 